\title{
WORK DEMANDS, INDEPENDENCE, VALUATION AS A FARMER, AND MENTAL HEALTH IN FARMING. A STUDY OF MENTAL HEALTH AMONG DAIRY FARMERS AND VEGETABLE- AND POTATO FARMERS IN NORWAY
}

\author{
Brit Logstein ${ }^{1}$
}

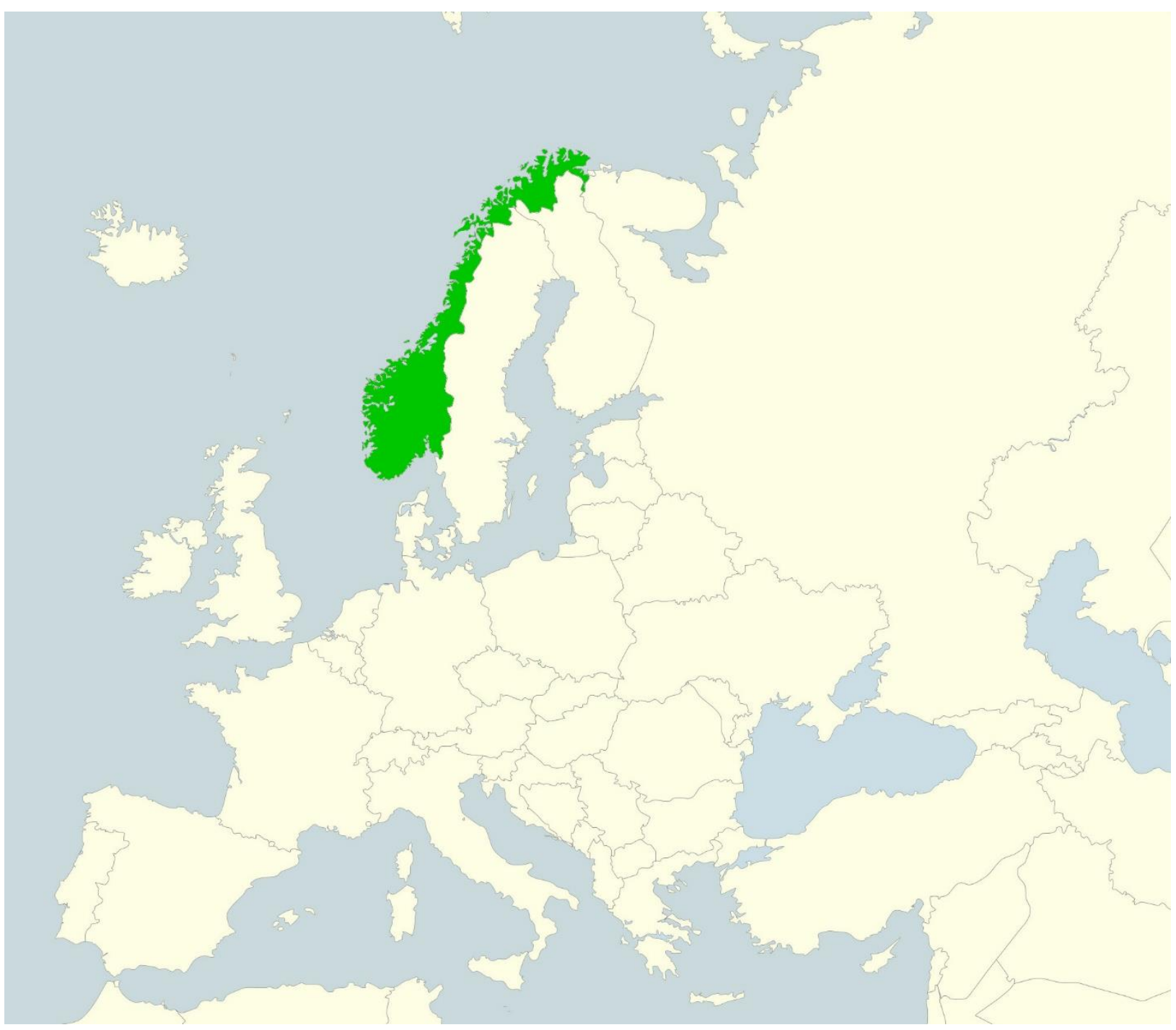

1 Brit Logsteil, PhD candidate, Institute for Rural and Regional Research, Norwegian University of Science and Technology Trondheim, Norway; email: brit.logstein@ruralis.no, ORCID: 0000-0003-1444-7148 
Abstract: In this study, the aim was to advance the knowledge about mental health status in the Norwegian farming population. Based on the dimensions in the Job Demand and Control model (Karasek, 1979); work demands and control, and the importance of recognition and dignity (Andrew Sayer, 2011), the aim was to study the effects of work demands, sense of independence and valuation on mental health status among farmers. It included an assessment of how the sectorial level, the sectors of dairy production and vegetable- and potato production, explains farmers' mental health status. A postal survey was conducted in 2012 using a structured questionnaire, and I included farmers from two sectors in the Norwegian agriculture: dairy farming $(n=493)$ and vegetable and potato farming $(n=122)$. The analyses were carried out by multigroup structural equation modeling (SEM). This study concludes that low work demands in farming, strong sense of independence as a farmer, and farmers perception of valuation associate with good mental health. The mental health status in dairy farmers and vegetable and potato farmers and the effects of work demands, sense of independence and valuation on mental health status, were equal across groups.

Keywords: Mental health, Independence, Work demands, Valuation, Self-employed farmers

\section{Highlights}

- The experience of valuation as farmer from the greater society, is important for farmers` mental health

- A strong sense of independence as a farmer is good for mental health

- Both the experience of valuation and sense of independence are partly rooted in farmers` identity as farmers, and not solely in activities at a day-to-day basis at the farm

\section{Introduction}

The agricultural sector has gone through considerable changes since the beginning of the twentieth century, globally as well as at national levels. In Western Europe and North America, the number of individuals employed in agriculture is constantly decreasing. However, agriculture have faced great advances in technology and farming practices. Individual farmers can manage larger acreages or handle enterprises that concentrate large number of livestock, poultry, or other productions (Frank, McKnight, Kirkhorn \& Gunderson, 2004). The price farmers tend to receive for their agricultural products have fallen, the need for investments and debt has increased, and farmers' net income has been relatively reduced since the 1990s (Lobley, Johnson, Reed, Winter \& Little, 2004). 'The outcomes of this agricultural restructuring on individual farmers' quality of life have often become synonymous with farming stress and mental difficulties' (Price and Evans, 2009, p.1).

Working in the agricultural sector, as well as to be a self-employed farmer, is found to be associated with a relative high risk of mental difficulties compared to other occupational groups. It is suggested that stress is a constant feature of contemporary farming (Melberg, 2001), often labelled farming stress (Price \& Evans, 2009). Farmers experience mental health problems more frequently than people working in other sectors (Hounsome, Edwards, Hounsome \& EdwardsJones, 2012), face a poorer health-related quality of life (Riise, Moen \& Nortvedt, 2003; Saarni, Saarni, \& Saarni, 2008), higher levels of depression symptoms (Sanne, Mykletun, Moen, Dahl, \& Tell, 2004; Torske, Hilt, Glasscock, Lundqvist \& Krokstad, 2016) and more symptoms of anxiety (Sanne et al., 2004).

As mental health is an important topic within agriculture, this study aimed to strengthen the knowledge about what factors impact farmers' mental health. 


\section{Scientific background}

Within research literature on farmers' mental health and well-being, a range of causes of the mental health issues and challenges identified in the farming population, are suggested. Causes found at the farm level and within farmers' daily work, often labelled stressors, are for instance, economic difficulties and risk of injuries and ergonomic hazards (Fraser et al., 2005), and time pressure and high work demands (Kallioniemi, Simola, Kaseva \& Kymäläinen, 2016; Kolstrup, 2014), including heightened administrative workload (Parry, Barnes, Lindsey \& Taylor, 2005). Farmers are found to have a significant higher index for psychological demands than individuals do in other occupations (Thelin, 1998), and psychological demands is also a risk factor for an increase in symptoms of mental distress (Kallioniemi, Simola, Kymäläinen, Vesala, \& Louhelainen, 2009; Kolstrup, 2014; Logstein, 2016).

In addition to factors at the farm level, also more perceptual factors in farmers 'life are found to be important for their mental health, such as their experience of high autonomy and independence as farmers. Autonomy and independence are important characteristics of western farming, and often highlighted as positive features, constituting important elements of farmers' identity (Holmberg, Thelin, Stiernström, \& Svärdsudd, 2004; Stock \& Forney, 2014; Sullivan, McCann, DeYoung \& Erickson, 1996). Autonomy related to decision-making and to the work situation itself is included in this cluster of independence (Bjørkhaug, 2006).

A strong sense of autonomy to decide on farm issues as opposed to being a subordinated wage laborer is closely connected to farmers' sense of pride (Dessein \& Nevens, 2007). Independence is also found to strengthen farmers' belief that external challenges and constraining structures can easily be met, and obstacles may easily be maneuvered and navigated around to find solutions (Stock \& Forney, 2014). Autonomy provides meaning in farming regardless of scale of the production (Schneider \& Niederle, 2010) and concerns not solely one type of farming nor where certain type of autonomy predominates.

As high work demands and independence in work constitute important aspects in farming, and both dimensions are important for their wellbeing as farmers, the Job-Demand-Control (JDC) model (Karasek, 1979; Karasek \& Theorell, 1990) is valuable to explain how independence and work demands could psychological affect health. In the JDC-model, work demands are aspects of the work environment such as demanding task requirements and time pressures. Job control is the breadth of skills workers can use in their work (skill discretion) and their authority over decision making (decision authority) in their work (Karasek \& Theorell, 1990).

In situations of high work demands and low autonomy, the individual is put in a situation of high strain. High demands lead to arousal of energy, but because of low level of control, the individual is not able to freely decide by him- or herself how to solve the obstacles, because he or she has no authority to make decisions regarding the situation. During high strain at work, the individual is put in a situation where the arousal of energy is transformed into damaging strain, and is associated with an increased risk of negative health outcomes such as fatigue, anxiety, depression and physical illness (Karasek \& Theorell, 1990). High strain as defined in the JDC model, corresponds with the concept of stress as an individual experience. High demands and challenging circumstances are understood as stressors (Aneshensel, 1992).

The individual could also be in situations of high work demands, but simultaneously high work control. Because an individual has the freedom to decide what the most effective course of action could be, he or she knows it is possible to modify the action if it failed or reinforce the strategy if it worked (Karasek \& Theorell, 1990). Learning, psychological growth and wellbeing are predicted as outcomes in situation of high work control, and farmers together with high-prestige occupations as lawyers and managers are found to be rated as having such jobs (Karasek \& Theorell, 1990). Even though there can be significant constraints on both decisions and practices in farmers' lives, their sense of autonomy is found to strengthen their belief that challenges can be met (Stock \& Forney, 2014).

In the literature of farming stress, Price and Evans (2009) found that the phenomena of stress in farming often is interpreted as ephemeral, where farming stress and mental difficulties are interpreted as an aspect at the farm level, without taking into consideration the more deep-seated 
structural and societal factors in farmers' lives. In this regard, farmers' relation to broader society where their farming occurs, and their subjective experience of this relationship must be considered. Farmers in western countries have traditionally been regarded as producers where the main function has been to produce food to the non-farming population (Vesala \& Vesala, 2010). Closely connected to farmers' pride, has been their identity as producers of the common good and a consciousness of how they through their own pursuit, produce food to the greater society they are a part of (Dessein \& Nevens, 2007). According to Vesala and Vesala (2010), farmers even tend to consider the role as a duty to the common good rather than serving their own economic interest. The society, to which farmers devote themselves into by producing food, might be an important source for assessing and evaluating how things they care about are valued, and hence which effect their sense of recognition and pride have on their self-esteem.

Farmers as a social group, have lost some of the positive and respected standing in the society that they once had (Shortall, 2014). In a study of Norwegian farmers, Barstad and Løwe (2009) found an increase in reported loneliness and dissatisfaction with farm income from 1995 to 2004. They see these trends in conjunction with `a general marginalization process in the agricultural sector` (Barstad \& Løwe, 2009, p.106). In Australian agriculture, mental difficulties and high rates of suicide among farmers have been explained through changes in farmers' social position in the society where they to a lesser extent are producers of the common good of the nation. These changes have led to a decrease in farmers`own self-worth and pride (Bryant \& Garnham, 2015) and farmers more frequently experience untrustworthiness from the government and the wider society (Polain, Berry, \& Hoskin, 2011). The media and public perceptions of farmers have also been found to be important stressors among farmers (Parry et al., 2005).

According to Sayer (2011), our employment status and the actual work we are doing is an important part of our identity and an important source of fulfilment. The recognition we get in that regard, has a major impact on our well-being. Further, our individual's mental well-being is influenced by how others evaluate things we care deeply about. When we evaluate ourselves as receiving low recognition from other individuals or groups in our society, the consequences can be negative feelings such as shame. How we stand in the eyes of others is often even more important to us than our actual wealth (Sayer, 2000, 2010).

\section{The Norwegian agricultural sector}

Norway has a population size of 5.2 million people distributed on $385186 \mathrm{~km}$. Mountains, waters and forests, and nordic climate, leaves only $3 \%$ of the land area utilized for agricultural production ${ }^{2}$. The Norwegian agricultural sector is highly politicized and the markets for agricultural products are regulated (see e.g.Almås 2004). The rationale for market regulations is to secure stability in the marked agricultural products and to avoid large fall or rise in prices, meaning securing a high degree of predictability for all actors in the food market, including the farmers. The government also supports domestic production by customs duty on imports (Almås 2004). In Norway, food security has been identified as one of the main goals of the agricultural policy, and the multifunctional role of agriculture is strongly embedded in public policy. From this perspective, the agricultural sector has several functions beyond the production of food and fibre (Rønningen, Renwick and Burton, 2012), including sustaining the viability of rural areas, preserving cultural heritage, conserving land, maintain agricultural landscapes, and supporting agro-biological diversity (Bjøkhaug and Richards, 2008).

Still, different farm productions and the total population of farmers in Norway have important characteristics in common, two farm productions can be described to be in each end of the scale from high regulation to low regulation. These are the dairy sector and vegetable- and potato sector. In Norway, the dairy sector is the most regulated (Almås \& Brobakk, 2012), and in combination with meat production, the most prevalent agricultural production in Norway. In 2012, farmers with dairy production amounted to $24 \%$ of the total number of self-employed farmers in Norway with 10700 dairy farmers. The average herd size was 23 milking cows ${ }^{3}$. The dairy sector

\footnotetext{
2 http://www.ssb.no/natur-og-miljo/statistikker/arealstat

${ }^{3}$ https://www.ssb.no/statbank/table/05986
} 
has its own market regulator, TINE SA. This farmer owned dairy cooperative regulates the market by assessing the market balance, is obliged to receive all milk from farmers with a quota, and distributes the available volume of milk to various dairy applications according to the industry's order (Almås \& Brobakk, 2012). Secured by this system, Norwegian dairy farmers are in a privileged position of relatively low economic risks and high economic stability, compared to dairy farmers in countries where the sector is deregulated (Almås \& Brobakk, 2012).

In the vegetables and potato sector, the situation is different. Unlike the dairy sector, there is no operating marked regulator. The Directorate of Agriculture monitors the marked. If the prices on farm products for more than two weeks exceeds the prices that were agreed upon between the government and the two farmers' organizations, the import restrictions on the same products will be lessened and the prices will decrease. The farmers do not have guaranteed delivery but need to have a contract with an industrial player, so-called contract farming. The contracts often last for only one or two years (Rønning, Vik, \& Magnus, 2013). Through a contract, the farmers commit themselves to deliver farm products to the customer, but it is not warranted that their products will reach the market in the end. End market depends on the current market potential. Within this model, it is the farmers that run the financial risks. The farmers own the production, including the financial investments, as well as the farm products until they are sold. In this system, farmers are confronted with insecurity beyond their control and depend on stability in the retail chain.

However, stability has not been the norm in recent years ${ }^{4}$. From 2010 to 2012, the number of vegetable farmers in Norway decreased from 3839 to 3216 , while the yield of vegetables did not change ${ }^{5}$. Development of contract farming has proved to be a powerful driver of structural changes in this sector. The incentive of the wholesalers is to reduce the number of suppliers, in order to minimize their own supply costs. When one farmer quits, the wholesaler often offers the vacant volume of supply to current suppliers, according to the farmers (Rønning et al., 2013).

Rønning et al. (2013) found that contract farming compared to guaranteed delivery of farmers` products creates a tougher context for farmers to operate in. Vegetable and potato farmers were found to experience uncertainty because of the terms of the contract, and they were complaining about the unequal power balance between themselves and the wholesalers. According to Bryant and Garnham (2014), the experience of being treated unfairly in an economic relationship with a wholesalers where farmers often have a weak position at the end of the value chain as food producers, could threaten farmers' self-worth and mental wellbeing. Vegetable- and potato farmers in Norway are situated in what Vesala and Peura (2005) described as asymmetrical relationships, and in a relationship between a big purchaser and a farmer, the farmer's experience of autonomy and control could be considerable restricted (Pritchard, Burch, \& Lawrence, 2007).

In addition to these differences in how the market is regulated, their type of work is obviously different. Dairy farmers are responsible for their livestock 365 days a year, and their possibilities to take a leave or a holiday are far more restricted, compared to vegetable- and potato farmers and other groups in the Norwegian society in general. Vegetable- and potato farmers have rather intensive periods in the short Norwegian season from spring to autumn, while less to do in other parts of the year. Løwe (2004) found in a study of Norwegian farmers that dairy farmers compared to farmers with other agricultural productions have a more physically and mentally demanding work and to a higher extent exposed to noise and contamination. This corresponds with (Kolstrup et al., 2013) who found that dairy farming globally is characterised by high workload, economic difficulties partly due to the need for large investments, high expectations from the society about social and environmental responsibility, and high responsibility and great requirements to safeguard the welfare of the animals in their care.

\footnotetext{
${ }^{4}$ Potential buyups and internal changes between the wholesale customers could have consequences for their contracts. In 2012, four wholesale actors dominated the food sector in Norway: Ica, REMA, Norgesgruppen and Coop. In 2014, Coop bought up Ica, and the destiny of 150 farmers where suddenly in the hands of new owners. Their contracts with Coop were no longer valid. After the restructuring, $25 \%$ of the farmers from the lca system no longer had a contract with a wholesaler to sell their farm products.

${ }^{5}$ https://www.ssb.no/en/jord-skog-jakt-og-fiskeri
} 
Both groups of farmers face factors that may have an impact on their farm business, but which are outside their control. Farmers within the sector of potato and vegetable are to a higher extent than dairy farmers prone to harsh climate and bad weather, running the risk of crop failures. Livestock farmers run the risk of be concerned about disease outbreaks for instance, which is also the case in horticulture.

In this study, the aim was to analyse how different aspects of farmers' lives explain their mental health status. These aspects are their self-reported work demands in farming, their sense of independence as a farmer, and their experience of valuation. To take into account how also the sectorial level might impact mental health, this study compared mental health status between dairy farmers and vegetable- and potato farmers and to what extent the effects of work demands, sense of independence and valuation on mental health status are different between sectors; dairy, and vegetable and potato.

In order to examine the relationships highlighted in the scientific literature on farming and mental health, I developed three hypotheses to address the Norwegian case:

Hypothesis 1: A strong sense of independence as a farmer associates with a good mental health

Hypothesis 2: An increase in experienced farm-work demands associates with a worse mental health status

Hypothesis 3: A strong sense of being valued by the broader society associates with a good mental health

Because these two sectors are different on several parameters, I included an investigation of to what extent the associations outlined in the three hypotheses are equal or not across the two groups of farmers, and to what extent the levels of mental health, independence as farmers, their experience of work demands, and the experience of being valued as a farmer by the society, are different between these groups. In the following chapter, I will elaborate on the details on data and methods used.

\section{Material and method}

This study had a cross-sectional design, and the data is collected through a questionnaire sent out to 7500 farmers in Norway, in 2012.

\section{Sample characteristics}

A random sample of 7,500 single principal owner-operators in farming in Norway was invited to participate in a postal survey in 2012, and 2,967 farmers agreed to answer the questionnaire (40\%). Storstad, Holte, \& Aas (2013) did an estimation of the representativeness of this sample of 2,967 farmers. They found that the sample has approximately the same distribution as in the population regarding age and gender. In the net sample of 2,967 farmers, the dairy farmers constituted 23 percent $(n=683)$, while in the population, the proportion was 22 percent. Vegetable and potato farmers constituted 6.6 percent $(n=258)$ of the sample. In the farm population, 5 percent were potato farmers and 2 percent are vegetable farmers. Within the aim of the study, I included only dairy farmers and vegetable- and dairy farmers in the further analyses. To be sure that those included in this study are either actual dairy farmers or actual vegetable and potato farmers, dairy farmers who had less than ten dairy cows and vegetable and potato farmers who operate on less than five hectares, were excluded. In the group of dairy farmers, I excluded those who combine dairy farming with vegetable- and potato production, fruit production and pig production, and in the other group, I excluded those who combine their vegetable and potato production with fruit production, indoor vegetables, milk or meat production and pig production. After these procedures, the sample size was reduced to from $n=941$ (dairy $=683$ and vegetable and potato farmers $=258$ ) to $n=765$ (dairy $=532$ and vegetable and potato $=133$ ).

The mean age of the farmers in these two groups were almost 52 years (Dairy farmers: mean age $=51.7$ and standard deviation $(\mathrm{sd})=10.22$, vegetable- and potato farmer: mean age $=51.6$ and $s d=9.53$ ). The proportions of female farmers were almost the same in the groups: 10 percent in the group of dairy farmers and 8 percent in the group of vegetable and potato farmers. In 
the main sample of 2967 farmers, the mean age was 53 years and female farmers constituted 12 percent. In the population of Norwegian farmers, the mean age was 50 years and female farmers constituted $14 \%$ of the total population (Logstein, 2012). In Table 1, the sample characteristics regarding workload in farming, net income from farming, and workload off-farm are presented. Regarding the farmers' individual workload in farming, 93 percent of the dairy farmers have a workload in farming of one person-year of work or more, while the proportion is lower among vegetable- and potato farmers $(56 \%)$. Potato- and vegetable farmers have a higher net income from agriculture, compared to dairy farmers. Almost 33 percent of vegetable- and potato farmers have a net income above 400000 , and the proportion of dairy farmers with net income above the same level is $18 \%$. Relatively few dairy farmers (4.2\%) have a net income from farming below of 50000 NOK, while 17.5 percent of the vegetable and potato farmers had a net income below that level. Half of the dairy farmers do not have off-farm work, and 6 percent have one person-year of off- farm work or more. In the other group of farmers, 15.8 percent have one person-year or more of off- farm work.

Tab 1. Sample characteristics of dairy farmers and potato- and vegetable farmers (yearly).

\begin{tabular}{|c|c|c|}
\hline & Dairy production & $\begin{array}{l}\text { Potato- and } \\
\text { vegetables }\end{array}$ \\
\hline Farm workload & $(n=563)$ & $(n=132)$ \\
\hline 1-199 hours & $0.2 \%$ & $3 \%$ \\
\hline 200-849 hours & $1.6 \%$ & $15.9 \%$ \\
\hline 850-1699 hours & $5.2 \%$ & $24.2 \%$ \\
\hline 1700-2449 hours & $44 \%$ & $39.4 \%$ \\
\hline 2500 hours or more & $49 \%$ & $17.4 \%$ \\
\hline Farm income & $(n=568)$ & $(n=137)$ \\
\hline Below 50000 NOK & $4.2 \%$ & $17.5 \%$ \\
\hline 50 000-199999 NOK & $25.6 \%$ & $17.4 \%$ \\
\hline 200 000-399 999 NOK & $51.9 \%$ & $32.1 \%$ \\
\hline 400 000-499 999 NOK & $9.3 \%$ & $10.2 \%$ \\
\hline Above 500000 NOK & $9 \%$ & $22.6 \%$ \\
\hline Workload off-farm & $(n=532)$ & $(n=133)$ \\
\hline $\begin{array}{l}\text { Do not have off-farm } \\
\text { work }\end{array}$ & $52.3 \%$ & $40.6 \%$ \\
\hline 1-199 hours & $19.5 \%$ & $15 \%$ \\
\hline $200-849$ & $14.3 \%$ & $15 \%$ \\
\hline 850-1699 & $8.8 \%$ & $13.5 \%$ \\
\hline 1700 hours or more & $5.1 \%$ & $15.8 \%$ \\
\hline
\end{tabular}




\section{Measurements and analyses}

To estimate mental health status in this study, the farmers were asked about how bothered they had been in the last 14 days with the following mental complaints: feeling fearful (Fear), nervousness or shakiness inside (Nervous), feeling hopeless about the future (Hopeless), feeling blue (Blue), and worrying too much about things (Worry). The response options were from 1 (not bothered) to 4 (very bothered). These five items constitute the Symptoms Check List-5 (SCL-5), a five-item version of the Symptom Check List anxiety and depression subscales (SCL-25). The SCL-5 was used as a screening measure of mental health in several studies (e.g. Strand, Dalgard, Tambs \& Rognerud, 2003) and performs as well as the SCL-25 (Strand et al., 2003; Tambs \& Moum, 1993). Farmers with two or more missing values $(5.6 \%)$ were excluded, and other missing values were replaced with sample mean on each item ( $<0.5 \%$ missing). This procedure is in accordance with comparable studies (Strand et al., 2003; Tambs \& Moum, 1993). In the Pearson correlation analyses, separate for the two groups of farmers, the items were highly correlated $(r \geq .430)$. The inter-reliability of these items for the whole sample was acceptable (Cronbach alpha $=.865$ ). In a principal component analysis (PCA), only one component was extracted, and all items for both groups loaded above .740 on one component. In the descriptive analyses, the five items fell into one sum score variable $(1=$ minimum value and 4 the maximum value).

Farmers' experience of independence was relevant for hypothesis 1 and was measured by a single statement; As a farmer, I have a strong sense of independence in my work. The response option ranged from totally disagree (1) to totally agree (5). Missing values (3.2\%) were replaced by the mean value on this variable. To measure work demands (hypothesis 2 ), I had the following statements: It is required that I work very fast (Fast), It is required that I work very hard (Hard), and It is required that I do an excessive amount of work (Excessive). The response options were 1 (very seldom or never), 2 (seldom), 3 (sometimes) and 4 (very often). These items have also been used in other studies when measuring work demands (Fandiño-Losada, Forsell \& Lundberg, 2013). The number of missing values on each of these items ranged between 1.9 and 2.4 percent and 12 respondents $(1,8 \%)$ had two items or more missing and were excluded from the data set. Four respondents had one missing value and they were replaced by the median value. The three items of work demands were highly correlated and in the PCA-analysis, all three items loaded above .770 on one component. The internal consistency of these items was also acceptable (Cronbach's alpha $=.721$ among dairy farmers and Cronbach's alpha $=.798$ among vegetable and dairy farmers).

The questionnaire had four statements about valuation (hypothesis 3): As a farmers I feel being highly valued by the local community (Community), as farmers, I feel being highly valued by the consumers (Consumers), as a farmer I feel being highly valued by the media (Media), and as a farmers I feel being highly valued by the national politicians (Politicians). The response options ranged in five steps from strongly disagree (1) to strongly agree (5). The number of missing values ranged from 3.4 to 3.2 percent and missing values were replaced with the mean value on each item. The items of valuation were highly correlated for both groups and the inter-reliability was acceptable (Cronbach alpha $=.802$ for dairy farmers and Cronbach alpha $=.839$ for vegetableand potato farmers). At last, I ran a PCA separate for both groups, and found that all four items loaded above .700 on one component. In further analyses in the study, the three items of work demand, and the four items of valuation fell into two sum scores, Work demands and Valuation. The values ranged from minimum (1) to maximum (4) and minimum (1) and maximum (5) respectively.

In terms of workload in farming, farmers were asked to report the approximate number of annual hours of working, and there were 3.7 percent missing values on this variable. The missing values were replaced by the mean value. In the descriptive statistics, the variable farming workload was treated as a continuous variable. In the further analyses in the study, farming workload was categorized into a 11-point ordinal Likert scale. Amount of workload off-farm the last year was measured by the following response options: no off-farm work (1), 1-200 hours (2), 200850 hours (3), 850-1700 hours(4), 1700-2550 hours (5) and more than 2550 hours (6). The variable had 4.9 percent missing values and ten of the respondents were given the value 0 
because they also answered that 100 percent of the total household income comes from agriculture. The others (3.3\%) were given the mean value on this variable.

Concerning the variable measuring farm income, the levels of net farm income were categorized into 9 groups, ranging from below 50000 NOK to above 500000 NOK. After missing values on each variable in this study were taken care of, the final sample size was $n=615$ ( $n=493$ of dairy farmers and $n=122$ of vegetable - and potato farmers).

To investigate possible differences between the two farm groups regarding mental health status, sense of independence, work-demands and valuation by society, independent sample t-tests, were carried out. I also included farm workload, workload off-farm and net income from farming to investigate to what extent the two groups of farmers differ on these farm-related aspects.

To test the effects of independence (hypothesis 1), work demands (hypothesis 2) and the level of valuation (hypothesis 3 ) on mental health, I used structural equation modelling (SEM) and multi group SEM. Multi group SEM was relevant because I intended to test whether the effects from the independent variables to the dependent variable, mental health status, are equal or not across two groups (hypotheses 1-4). In general, a SEM-analysis can be divided into a measurement model and a structural model. A measurement model consists of associations between measured variables and one more latent variable. To develop a measurement model in SEM is often understood as a confirmatory factor analysis (CFA) in SEM, where simultaneous equations calculate the strength of the associations (Meredith \& Teresi, 2006). The advantage of using a latent variable instead of calculating a sum score by adding together a number of manifest variables, is that a latent variable is free of random measurement error, and estimation of associations that include such variables will be less biased (Christ, Lee, Lam \& Zheng, 2014; Muthén, 2002).

In this study, the dependent variable, mental health status, was a latent variable and I had five observable items (Fear, Nervous, Hopeless, Blue and Worry). After I had tested the latent variable in the whole sample, I ran an analysis of measurement invariance for these two groups of farmers. The analysis of measurement invariance of latent constructs is important in group comparisons. By establishing whether the main parameters of the measurement model are equivalent across groups or not, I can assure that comparisons of the latent variable across groups are valid. I carried out a multi group CFA to test for measurement invariance, and I tested four degrees of measurement invariance. Strict invariance is the highest degree of measurement invariance, where the factors loadings, the intercepts, residual variances and the covariance between the residuals are constrained to be equal across groups. Configural invariance is the lowest degree of measurement invariance and only the factor loadings are constrained to be equal (Meredith \& Teresi, 2006).

When running group comparisons in structural equation models, I was interested in investigating whether the effect of sense of independence in their work as a farmer $\left(\gamma_{11}\right)$, work demands in farming $\left(\gamma_{21}\right)$, and valuation $\left(\gamma_{41}\right)$ on mental health differ across the two groups, while adjusting for the effect of actual work-load in farming $\left(\gamma_{31}\right)$. In testing the models, different parameters were set to vary across groups, while others were constrained to be equal. To determine to what degree the measurement models and the structural models in this study are consistent with empirical data, I used several goodness-of- fit indices (Milfont \& Fischer, 2010). These are the maximum likelihood ratio chi-square (Chi-square), root mean square error of approximation(RMSEA), Comparative fit index (CFI), Tucker-Lewis index (TLI), the standardized root mean square residual (SRMR), Akaike`s Information Criterion (AIC) and Bayesian Information Criterion (BIC).

\section{Results}

In the independent-sample t-test, I found no significant difference in mental health status between dairy farmers and farmers running vegetable and potato production $(t=.973, p>.10)$. On a scale of 1 to 4 , the mean value for the whole sample was 1.39 , and 1.40 and 1.35 for dairy farmers and vegetable and potato farmers, respectively. In a study carried out in the Norwegian population 
over 15 years old in 1998, the mean value on the same measure of mental health status was 1.33, and among men, the mean value was 1.28 (Strand et al., 2003).

The self-reported level of work demands is significantly higher among dairy farmers than among vegetable and potato producers $(t=4.881, p<.01)$. The mean number of working hours in farming for the whole sample was 2357 hours, and the difference in the mean workload from dairy farmers to potato- and vegetable farmers is significant $(13.3, p<-01)$, the mean values were 2592 and 1410 hours respectively. Vegetable- and potato farmers had a significant higher work load offfarm $(t=5.648, p<.01)$, and dairy farmers had a significant higher net income from farming $(\mathrm{t}=4.325, \mathrm{p}<.01)$.

Tab 2. Descriptive statistics of how mental health status, valuation, work demands, the sense of independence, farm workload, workload off-farm and net income from farming are distributed among dairy and vegetable and potato farmers. Independent-sample t-test for test of group differences. Mean values, and SD in brackets.

\begin{tabular}{|l|c|c|c|c|}
\hline & $\begin{array}{c}\text { Dairy farmers } \\
\mathbf{n}=\mathbf{4 9 2}\end{array}$ & $\begin{array}{c}\text { Vegetable-and } \\
\mathbf{p o t a t o} \\
\mathbf{n}=\mathbf{1 2 2}\end{array}$ & $\begin{array}{c}\text { All farmers } \\
\mathbf{n}=\mathbf{6 1 4}\end{array}$ & $\begin{array}{c}\text { Test of group } \\
\text { differences }\end{array}$ \\
\hline Mental health status & $1.40(.52)$ & $1.35(.45)$ & $1.39(.50)$ & $\mathrm{t}=.973, \mathrm{p}>.10$ \\
\hline Valuation by society & $3.76(.73)$ & $3.73(.79)$ & $3.76(.74)$ & $\mathrm{t}=.454, \mathrm{p}>.10$ \\
\hline Work demands & $2.79(.53)$ & $2.52(.60)$ & $2.74(.55)$ & $\mathrm{t}=4.881, \mathrm{p}<.01$ \\
\hline $\begin{array}{l}\text { Sense of } \\
\text { independence }\end{array}$ & $2.37(.1 .0)$ & $2.21(.98)$ & $2.34(1.00)$ & $\mathrm{t}=1.633, \mathrm{p}>.10$ \\
\hline $\begin{array}{l}\text { Farm workload } \\
\text { (hours) }\end{array}$ & $2592(721.37)$ & $1410(913.55)$ & $\begin{array}{c}2357 \\
(897.59)\end{array}$ & $\mathrm{t}=13.299, \mathrm{p}<.01$ \\
\hline $\begin{array}{l}\text { Workload off-farm } \\
\text { Net income from }\end{array}$ & $1.92(1.18)$ & $2.75(1.51)$ & $2.08(1.29)$ & $\mathrm{t}=-5.648, \mathrm{p}<.01$ \\
farming & $6.10(1.73)$ & $5.01(3.65)$ & $5.88(1.99)$ & $\mathrm{t}=4.325, \mathrm{p}<.01$ \\
\hline
\end{tabular}

In the measurement model for the whole sample, all items loaded strongly on the latent variable and the variance on each item explained by the latent variable was acceptable (R-squared $>.40$ ). Fear was used to set the metric for the presumed latent variable, and its loading coefficient was 1.0. To assess the validity of the latent variable, I had the following values of goodness of fit: chi- square $=2.284(\mathrm{df}=5)$ and $p$-value $=0.0005, \mathrm{RMSEA}=0.075, \mathrm{CF} \mathrm{I}=0.971, \mathrm{TLI}=0.943$ and $\mathrm{SRMR}=0.030$. These values indicate that the latent variable has a good fit to the data (Schermelleh-Engel, Moosbrugger \& Müller, 2003). According to Ringdal and Wiborg (2017), the chi-square test is not suitable for sample $n>200$, where even models with a good fit tend to be rejected by the chi-square test.

In the multi-group-CFA, the best solution for measurement invariance was reached with strong invariance. Strong invariance means that the factor loadings and intercepts are equal, while the residual variance and the residual covariance vary across groups. According to Little (1997), strong factorial invariance is as a sufficient condition for doing between-group comparisons, and even a better solution than strict factorial invariance where the residual variances are also equated. Even though the distribution of random error could be quite similar across groups, the non-equal portions of the random error are forced into equal parameters, potentially introducing sources of bias. In the measurement model, the coefficients and the intercepts were set to be equal across groups, and I got the following goodness of fit statistics: Chi-square: 50.099 $(\mathrm{df}=18)$ and $\mathrm{p}$-value $=0.00, \mathrm{RMSEA}=0.076, \mathrm{CFI}=0.977, \mathrm{TLI}=0.975, \mathrm{SRMS}=0.055$, $\mathrm{AIC}=4321.868 .367$ and $\mathrm{BIC}=4419.144$. The parameters constrained to be equal and those not constrained to be equal in the two groups are presented in table 3 . As I can see, the variance in each item explained by the latent variable and the size of the residuals did not diverge so much across the groups. 
Of all different combinations, the best fit was reached when all four coefficients where constrained to be equal across the two groups. The results from the tests for group invariance of parameters for this model is presented in Table 4. None of the independent variables' effect on mental health were significantly different across the two groups of farmers ( $p$-values $>.05$ ).

Tab 3. The associations between the latent variable Mental health and the five manifest variables; Fear (X1), Nervous (X2), Hopeless (X3), Blue (X4), Worry (X5), operationalized by the following parameters: Factor loadings (coefficients- $\lambda 1$ ), intercepts $(\lambda 0)$, variance and residual covariance (R2). $\lambda 1$ and $\lambda 0$ constrained to be equal. Strong factorial invariance.

\begin{tabular}{|l|l|l|l|l|l|l|l|l|l|l|}
\hline & \multicolumn{5}{|c|}{ Dairy farmers } & \multicolumn{5}{c|}{ Vegetable- and potato farmers } \\
\hline & $\mathrm{X} 1$ & $\mathrm{X} 2$ & $\mathrm{X} 3$ & $\mathrm{X} 4$ & $\mathrm{X}$ & $\mathrm{X} 1$ & $\mathrm{X} 2$ & $\mathrm{X3}$ & $\mathrm{X} 4$ & $\mathrm{X5}$ \\
\hline $\mathrm{N1}$ & 1 & 1.70 & 1.69 & 1.67 & 2.02 & - & - & - & - & - \\
\hline $\mathbf{\lambda} 0$ & .501 & .274 & .345 & .267 & .310 & - & - & - & - & - \\
\hline Variance & .125 & .157 & .203 & .144 & .189 & .075 & .119 & .222 & .129 & .151 \\
\hline $\mathrm{R}^{2}$ & .407 & .613 & .548 & .626 & .649 & .504 & .649 & .495 & .623 & .673 \\
\hline
\end{tabular}

Tab 4. Tests for group invariance of parameters, when all gamma coefficients $(\gamma)$ are constrained to be equal across groups.

\begin{tabular}{lccc}
\hline Parameters & \multicolumn{3}{c}{ Score Test } \\
\hline & Chi2 & $\mathrm{df}$ & $\mathrm{P}>$ chi2 \\
\hline Independence $\left(\gamma_{\mathbf{1 1}}\right)$ & 0.000 & 1 & 0.9872 \\
& & & \\
\hline Work demands $\left(\gamma_{\mathbf{2 1}}\right)$ & 0.195 & 1 & 0.6590 \\
\hline Workload $\left(\gamma_{\mathbf{3 1}}\right)$ & 1.069 & 1 & 0.3013 \\
\hline Valuation $\left(\gamma_{\mathbf{4 1}}\right)$ & 0.041 & 1 & 0.8386 \\
\hline
\end{tabular}

The structural models are presented in Table 5. In model 1, all coefficients are constrained to be equal, and in model 2 , none are constrained. In model 1, I got the following fit statistics: Chi- square $=118.577(\mathrm{df}=55)$ and $\mathrm{p}$-value $=0.000, \mathrm{RMSEA}=0.061, \mathrm{CFI}=0.958, \mathrm{TLI}=0.954$, $\mathrm{SRMR}=0.075, \mathrm{AIC}=12857.121$ and $\mathrm{BIC}=12967.661$. The fit of model 2 was not as good as the fit of model 1: Chi- square $=115.190(\mathrm{df}=51)$ and $\mathrm{p}$-value $=0.000$, RMSEA $=0.064$, $\mathrm{CFI}=0.958, \mathrm{TLI}=0.950, \mathrm{SRMR}=0.070, \mathrm{AIC}=12861.734$ and $\mathrm{BIC}=12989.962$ (van de Schoot, Lugtig \& Hox, 2012). 
Tab 5. The structural model, where mental health is the dependent variable. All gamma coefficients of the independent variables, independence $\left(\gamma_{11}\right)$, work demands $\left(\gamma_{21}\right)$ work load $\left(\gamma_{31}\right)$ and valuation $\left(\gamma_{41}\right)$. All constrained to be equal (1) and none constrained to be equal across groups (2). Standard error (SE) and p-value. Standardized $\checkmark$ coefficients in model 1. In model 2 , the values for the vegetable and potato farmers in brackets.

\begin{tabular}{lccc|ccc}
\hline \multicolumn{2}{l}{ 1. All constrained } & & & \multicolumn{4}{l}{ 2. None constrained } \\
\hline \\
\hline
\end{tabular}

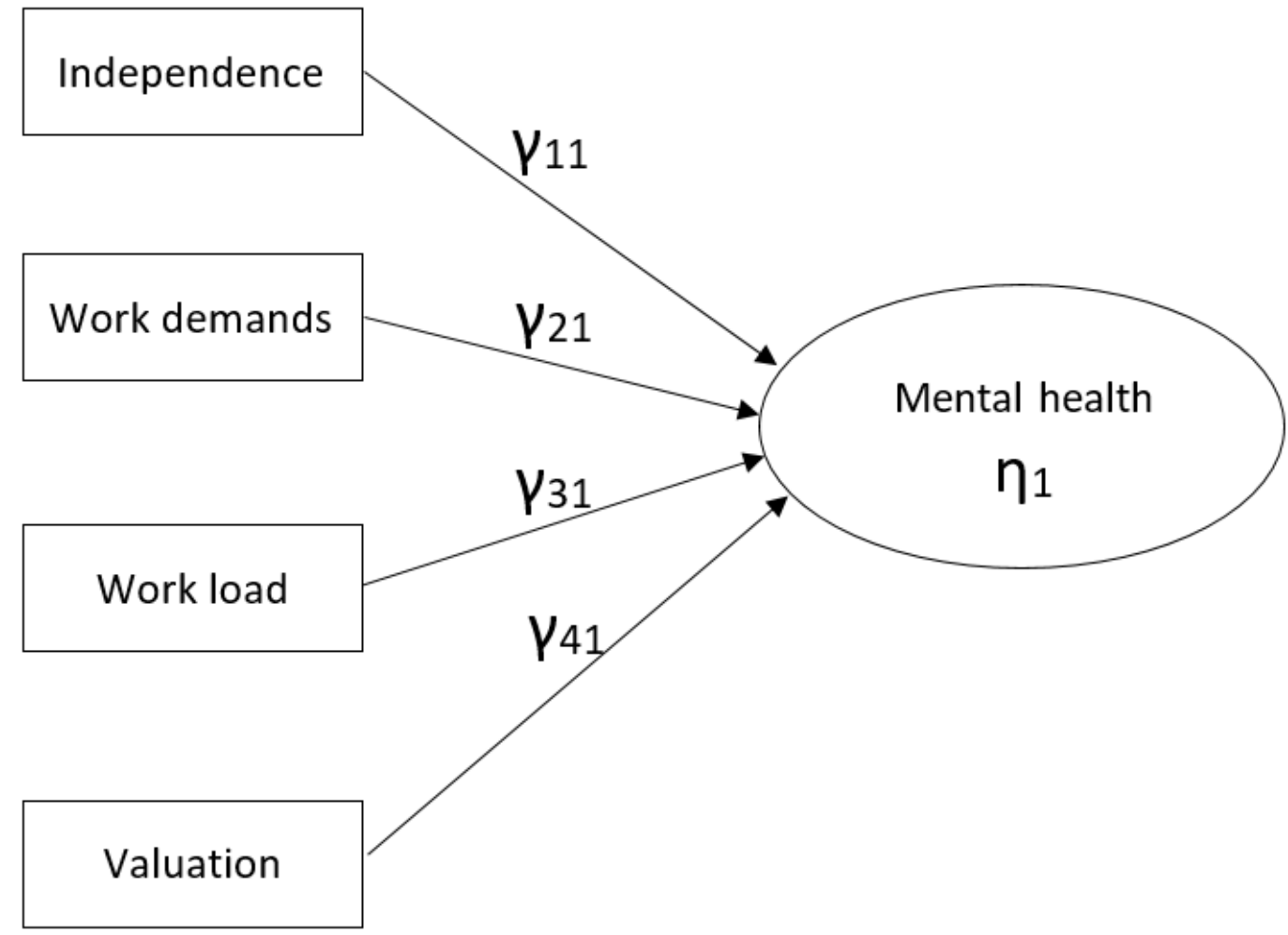

Fig 1. Path diagram for the structural model. Mental health the dependent variable and independence, work demands, work load and valuation the independent variables.

The main findings from this SEM-analysis were found in model 1 where all effects are constrained to be equal across groups. A decrease in the sense of independence as a farmer and an increase in work demands in farming associated with a worse mental health $(B=-.0475$ and $B=.0441$, respectively). At last, the experience of valuation had a significant effect on mental complaints in both groups $(\mathrm{B}=-.0458)$. The effects are equal across both groups. Because the gamma coefficients were the same across both groups, I also presented the standardized gamma coefficients. By using the standardized values, different independent variables are comparable, and I see that work demands have the strongest effect (.287). In model 1, 12.6 percent and 
13.9 percent of the variance of the dependent variable mental complaints, for dairy farmers and vegetable- and potato farmers respectively, were explained by the four independent variables $\left(R^{2}=.1259\right.$ and $\left.R^{2}=.1389\right)$. Across the two models (model 1 and model 2$)$, the results were relatively stable, and it is correct to choose the model with the best fit.

\section{Discussion}

In this study of farmers' mental health, I tested three hypotheses. The first one: that a strong sense of independence as a farmer, both for dairy farmers and vegetable- and potato farmers, associates with a good mental health, was confirmed. Our findings deviate from Melberg (2003), who found that the apparent freedom inherent in the work situation did not have a significant influence on Norwegian farmers' well-being. Our finding that farmers' sense of independence as a farmer influences their mental health positively is in line with Karasek and Theorell (1990). As the degree of sense of independence in the two farm groups were equal, even though they differ on certain sector specific characteristics, it is reasonable to propose that farmers sense of independence is at least partly rooted in their subjectivity, and not solely relates to the actual work characteristics, corresponding to Stock and Forney (2014). The agricultural sector is constantly changing, due to agricultural policy and regulations, technological innovations and the market and access to markets for agricultural products. This inherent belief that they are independent as farmers and thus have a possibility to maneuver if needed, may be of great importance when farmers face challenges and consider fundamental or strategic adjustments of their farm business (Morgan, Marsden, Miele \& Morley, 2010).

The second hypothesis was also confirmed: An increase in self-reported farm-related work demands associates with an increase in mental complaints, and correspond with other studies (e.g. Kolstrup, 2014). In addition, the effect of work-demands on mental health were equal across both groups. This is what was expected, but still important finding, as we know that the farming populations are faced with high work demands.

To be valued as a farmer by the greater society they are a part of associates with a better mental health (hypothesis 3). To be able to deal more sensitively and effectively in the development of strategies aiming to promote mental health and well-being in the farming population, an awareness of how farmers ' own subjective experience of their position, is therefore of high value (Price \& Evans, 2009). The mean values on the sum score of valuation among dairy and vegetable- and potato farmers, and the effect of valuation on mental health status across the two groups were equal, despite the fact that their relationship with the society through different levels of governmental regulation and surveillance of the market for food could be understood to be quite different (Pritchard et al., 2007; Lockie, Lawrence \& Cheshire, 2006). An explanation might be that these two groups of farmers as part of the multifunctional agriculture in Norway share many of the same roles. To be valued as a farmer by the greater society, might therefore not necessary be attached only to their main production, but to other roles, expectations and even a common identity they have as farmers through several roles in the Norwegian society. This coincides with other studies such as Vayro, Brownlow, Irland and March (2002), where they found that the life of farmers not only relates to the specific tasks in their farm operations and resources such as time and finance, but also through farmers' identity and common culture.

I also aimed to study, unadjusted, how these two groups of farmers differ in their sense of work demands, annual workload in farming, workload off-farm and net income from farming. The level of self-reported work demands, and annual farm workload were significantly higher among dairy farmers. That corresponded with Simkin, Hawton, Fagg, \& Malmberg (1998) and (Løwe (2004). At last, vegetable and potato farmers had a higher farm income compared to dairy farmers. In this study, I did not include the dimensions of gender and age in the final analyses of how independence, work demands, and valuation predict mental health, across two groups of farmers. From other studies, both age and gender have shown to associate with mental health among farmers (e.g. Torske, Hilt, Glasscock, Lundqvist \& Krokstad, 2016). As I was interested to include an investigation of what extent the association between independence, work demands, workload and valuation, and the dependent variable mental health, differ between groups of farmers, it became outside the scope of the article to include age and gender in the final analyses. For further 
research, it will be important to investigate how these dimensions and their association with mental health differs between different groups of farmers.

\section{Potential limitations}

In this study, the cross-sectional design is a limitation that hinders a secure conclusion about causality between the independent variables in the study and the dependent variable, mental health. I used a dependent variable that assesses the total load of both anxiety and depression symptoms. In the interpretation of the final results, it is important to take into account that the findings in the study may be somewhat different when using other measures of mental health, or if symptoms of anxiety and symptoms of depression were treated as two separate scales. In this study, it was important to secure that their farm operations where mainly related to dairy production or vegetables- and/or potato production, but it could be a limitation that I excluded farmers who combine different farm productions. Farmers who were not in the population, are those who probably failed to get a contract with the cooperatives or retail chain, and thus the sample consists mainly of the most successful farmers.

\section{Conclusions}

To reach an understanding of farming mental health status, I found that work demands, independence and valuation are important for farmers' mental health. High work demands, low sense of independence at work and low valuation in the greater society have a negative impact on mental health among dairy and vegetable and potato farmers. Within a Norwegian context, I was not able to find that the sectorial level, dairy vs vegetable and potato production, explain differences in mental health status among farmers, or that sense of independence, valuation and work demands had unequal effect on mental health status across the two groups of farmers.

\section{Acknowledgements}

The author is grateful to Kristen Ringdal for advice regarding the statistical analyses, advice on how to improve the manuscript and for reading through the manuscript before publishing. The author is grateful to Hilde Bjørkhaug and Reidar Almås because of their advices on how to improve the manuscript and for reading through the manuscript before publishing. Finally, I am very grateful to the two anonymous reviewers reviewing this article before publishing.

Funding: This work was supported by the Research Council and Agricultural Agreement Research Fund $(208053 / 110)$.

\section{Academic references}

[1] Almås, R. (2004). Norwegian Agricultural History. Trondheim: Tapir Academic Publishers.

[2] Almås, R. \& Brobakk, J. (2012). Norwegian dairy industry: A case of super-regulated cooperativism. In Almås, R. \& Campbell, H., eds., Rethinking Agricultural Policy Regime. Food security, Climate Change and the Future Resilience of Global Agriculture (Volume 18, pp. 169-189). Bingley: Emerald.

[3] Aneshensel, C. S. (1992). Social Stress Theory and Research. Annual Review of Sociology, 18, 15-38. DOI: 10.1146/annurev.so.18.080192.000311.

[4] Barstad, A. \& Løwe, T. (2009). Livskvalitet og sosial integrasjon i landbruket. In Levekår i landbruket 1995-2004: Livsformer og rammebetingelser i endring. Statistiske analyser 108/2009. Oslo: Statistic Norway.

[5] Bjørkhaug, H. (2006). Sustainable agriculture in the Norwegian farmers' context. Exploring farming habitus and practice on the Norwegian Agricultural Field. International Journal of Environmental, Cultural, Economic and Social Sustainability, 2(4), 123-131. DOI: $10.18848 / 1832-2077 / C G P / v .02 i 04 / 54241$. 
[6] Bjørkhaug, H. \& Richards, C. A. (2008). Multifunctional Agriculture in Policy and Practice? A Comparative Analysis of Norway and Australia. Journal of Rural Studies, 24, 98-111. DOI: 10.1016/j.jrurstud.2007.06.003.

[7] Bryant, L. \& Garnham, B. (2014). Economies, ethics and emotions: Farmer distress within the moral economy of agribusiness. Journal of Rural Studies, 34, 304-312. DOI: 10.1016/j.jrurstud.2014.03. 006.

[8] Bryant, L. \& Garnham, B. (2015). The fallen hero: masculinity, shame and farmer suicide in Australia. Gender, Place and Culture, 22(1), 67-87. DOI: 10.1080/0966369X.2013.855628.

[9] Christ, S. L., Lee, D. J., Lam, B. L. \& Zheng, D. D. (2014). Structural equation modeling: A framework for ocular and other medical sciences research. Ophthalmic Epidemiology, 21, 1-13. DOI: 10.3109/09286586.2013.867508.

[10] Dessein, J. \& Nevens, F. (2007). 'I'm sad to be glad'. An analysis of farmers ' pride in Flanders. Sociologia Ruralis,47(3), 273-292. DOI: 10.1111/j.1467-9523.2007.00437.x.

[11] Fandiño-Losada, A., Forsell, Y. \& Lundberg, I. (2013). Demands, skill discretion, decision authority and social climate at work as determinants of major depression in a 3-year followup study. International Archives of Occupational and Environmental Health. DOI: 10.1007/s00420-012-0791-3.

[12] Frank, A. L., McKnight, R., Kirkhorn, S. R. \& Gunderson, P. (2004). Issues of Agricultural Safety and Health. Annual Review of Public Health. DOI: 10.1146/annurev.publhealth.25.101802.123007.

[13] Fraser, C. E., Smith, K. B., Judd, F., Humphreys, J. S., Frager, L. J. \& Henderson, A. (2005). Farming and mental health problems and mental illness. International Journal of Social Psychiatry,51(4), 340-349. DOI: 10.1177/0020764005060844.

[14] Holmberg, S., Thelin, A., Stiernström, E. L. \& Svärdsudd, K. (2004). Psychosocial factors and low back pain, consultations, and sick leave among farmers and rural referents: A population-based study. Journal of Occupational and Environmental Medicine, 46(9), 993998. DOI: 10.1097/ 01.jom.0000137715.33662.02.

[15] Hounsome, B., Edwards, R. T., Hounsome, N. \& Edwards-Jones, G. (2012). Psychological morbidity of farmers and non-farming population: Results from a UK survey. Community Mental Health Journal,48(4), 503-510. DOI: 10.1007/s10597-011-9415-8.

[16] Kallioniemi, M. K., Simola, A., Kaseva, J. \& Kymäläinen, H. R. (2016). Stress and burnout among Finnish dairy farmers. Journal of Agromedicine, 21(3), 259-268. DOI: 10.1080/1059924X.2016.1178611.

[17] Kallioniemi, M. K., Simola, A., Kymäläinen, H. R., Vesala, H. T. \& Louhelainen, J. K. (2009). Mental symptoms among finnish farm entrepreneurs. Annals of Agricultural and Environmental Medicine,16(1), 159-168. DOI: 10.1080/1366271032000141661.

[18] Karasek, R. A. (1979). Job Demands, Job Decision Latitude, and Mental Strain: Implications for Job Redesign. Administrative Science Quarterly, 24(2), 285-308.

[19] Karasek, R. A. \& Theorell, T. (1990). Healthy Work: Stress, Productivity and the reconstruction of working life. New York: Basic Books.

[20] Kolstrup, C., Kallioniemi, M., Lundqvist, P., Kymäläinen, H. R., Stallones, L. \& Brumby, S. (2013). International perspectives on psychosocial working conditions, mental health, and stress of dairy farm operators. Journal of Agromedicine,18(3), 244-255. DOI: 10.1080/1059924X.2013.796903.

[21] Kolstrup, C. L. (2014). Lantbrukares psykosociala arbetsvillkor, psykiska hälsa och stress $i$ ett svenskt och internationellt perspektiv-Kunskapssammanställning. Rapport 2014:28. Alnarp: Sveriges lantbruksuniveristet. 
[22] Little, T. D. (1997). Mean and Covariance Structures (MACS). Analyses of Cross-Cultural Data: Practical and Theoretical Issues. Multivariate Behavioural Research,32(1), 53-76. DOI: 10.1207/s15327906mbr3201_3.

[23] Lobley, M., Johnson, G., Reed, M., Winter, M. \& Little, J. (2004). Rural Stress Review: Final Report. Exeter: University of Exeter.

[24] Lockie, S., Lawrence, G. \& Cheshire, L. (2006). Reconfiguring rural resource governance: The legacy of neo-liberalism in Australia. In Handbook of Rural Studies (pp. 29-44). DOI: $10.4135 / 9781848608016 . n 3$.

[25] Logstein, B. (2012). Trender $i$ norsk landbruk 2012. Trondheim: Norsk senter for bygdeforskning.

[26] Logstein, B. (2016). Farm-related Concerns and Mental Health Status Among Norwegian Farmers. Journal of Agromedicine, 21(4), 316-326. DOI: 10.1080/1059924X.2016.1211055.

[27] Løwe, T. (2004). Bonden arbeider hardt for føden. Samfunnsspeilet 2004/05. Kongsvinger/Oslo: Statistic Norway.

[28] Melberg, K. (2001). Farming, stress and psychological well-being. Sociologia Ruralis 43(1), 56-76. DOI: 10.1111/1467.9523.00229.

[29] Meredith, W. \& Teresi, J. A. (2006). An essay on measurement and factorial invariance. Medical Care 44(11), 569-577. DOI: 10.1097/01.mlr.0000245438.73837.89.

[30] Milfont, T. L. \& Fischer, R. (2010). Testing measurement invariance across groups: Applications in cross-cultural research. International Journal of Psychological Research 3(1), 111-130. DOI: $10.21500 / 20112084.857$.

[31] Morgan, S. L., Marsden, T., Miele, M. \& Morley, A. (2010). Agricultural multifunctionality and farmers' entrepreneurial skills: A study of Tuscan and Welsh farmers. Journal of Rural Studies,26, 116-129. DOI: 10.1002/rnj.205.

[32] Muthén, B. O. (2002). Beyond SEM: general latent variable modeling. Behaviormetrika, 29, 81-117. DOI: 10.2333/bhmk.29.81.

[33] Parry, J., Barnes, H., Lindsey, R. \& Taylor, R. (2005). Farmers, farm workers and workrelated stress. A report for the health and safety executive [Research Report 362]. London: Policy Studies Institute.

[34] Polain, J. D., Berry, H. L. \& Hoskin, J. O. (2011). Rapid change, climate adversity and the next "big dry": Older farmers' mental health. The Australian Journal of Rural Health, 19(5), 239-243. DOI: 10.1111/j.1440-1584.2011.01219.x.

[35] Price, L. \& Evans, N. (2009). From stress to distress: Conceptualizing the British family farming. Journal of Rural Studies, 25(1), 1-11. DOI: 10.1016/j.jrurstud.2008.03.008.

[36] Pritchard, B., Burch, D. \& Lawrence, G. (2007). Neither "family" nor "corporate" farming: Australian Tomato Growers as Farm Family Entrepreneurs. Journal of Rural Studies, 23(1), 75-87. DOI: 10.1016/j.jrurstud.2006.04.001.

[37] Riise, T., Moen, B. E. \& Nortvedt, M. W. (2003). Occupation, lifestyle factors and healthrelated quality of life: The Hordaland Health Study. Journal of Occupational and Environmental Medicine, 45(3), 324-32. DOI: 10.1097/01.jom.0000052965.43131.c3.

[38] Ringdal, K. \& Wiborg, Ø. (2017). Lær deg stata. Innføring i statistisk dataanalyse. Bergen: Fagbokforlaget.

[39] Rønningen, K., Renwick, A. \& Burton, R. (2012). Western European Approaches to an Interpretation of Multifunctional Agriculture and Some Implications of a Possible NeoProductivist turn. In Almås, R. \& Campbell, H., eds., Rethinking Agricultural Policy Regimes: Food Security, Climate Change and the Future Resilience of Global Agriculture (pp. 73-98). Bingley: Emerald Group Publishing. 
[40] Rønning, L., Vik, J. \& Magnus, T. (2013). Kontraktproduksjon i landbruket. En annen hverdag for bonden [Rapport 1/13]. Trondheim: Norsk senter for bygdeforskning.

[41] Saarni, S. I., Saarni, E. S. \& Saarni, H. (2008). Quality of life, work ability, and selfemployment: A population survey of entrepreneurs, farmers, and salary earners. Occupational and Environmental Medicine, 65(2), 98-103. DOI: 10.1136/oem.2007.033423.

[42] Sanne, B., Mykletun, A., Moen, B. E., Dahl, A. A. \& Tell, G. S. (2004). Farmers are at risk for anxiety and depression: The Hordaland Health Study. Occupational Medicine,54(2), 92-100. DOI: $10.1093 /$ occmed/kgh007.

[43] Sayer, A. (2000). Moral Economy and Political Economy. Studies in Political Economy,61, 79-104. DOI: 10.1080/19187033.2000.11675254.

[44] Sayer, A. (2010). Class and morality. In Hitlin, S. \& Vaisey, S., eds., Handbook of the Sociology of morality (pp. 163-178). New York: Springer.

[45] Sayer, A. (2011). Why things matter to people: Social sciences, values and ethical life. New York: Cambridge University Press. DOI: 10.1007/978-1-4419-6896-8.

[46] Schermelleh-Engel, K., Moosbrugger, H. \& Müller, H. (2003). Evaluating the Fit of Structural Equation Models: Tests of Significance and Descriptive Goodness-of-Fit Measures. Methods of Psychological Research Online 8(2), 23-74.

[47] Schneider, S. \& Niederle, P. A. (2010). Resistance strategies and diversification of rural livelihoods: The construction of autonomy among Brazilian family farmers. Journal of Peasant Studies,37(2), 379-405. DOI: 10.1080/03066151003595168.

[48] Shortall, S. (2014). Farming, identity and well-being: Managing changing gender roles within Western European farm families. Anthropological Notebooks, 20(3), 67-81.

[49] Simkin, S., Hawton, K., Fagg, J. \& Malmberg, A. (1998). Stress in farmers: A survey of farmers in England and Wales. Occupational and Environmental Medicine,55, 729-734. DOI: 10.1136/oem.55.11.729.

[50] Stock, P. V. \& Forney, J. (2014). Farmer autonomy and the farming self. Journal of Rural Studies,36, 160-171. DOI: 10.1016/j.jrurstud.2014.07.004.

[51] Storstad, O., Holte, K. A. \& Aas, O. (2013). Ulykker og arbeidsmiljø i landbruket. Et første overblikk over sentrale HMS-forhold [research report]. Trondheim: Norsk senter for bygdeforskning.

[52] Strand, B. H., Dalgard, O. S., Tambs, K. \& Rognerud, M. (2003). Measuring the mental health status of the Norwegian population: A comparison of the instruments SCL-25, SCL-10, SCL5 and MHI-5 (SF-36). Nordic Journal of Psychiatry. DOI: 10.1080/08039480310000932.

[53] Sullivan, S., McCann, E., DeYoung, R. \& Erickson, D. (1996). Farmers' attitudes about farming and the environment: A survey of conventional and organic farmers. Journal of Agricultural and Environmental Ethics, 9(2), 123-143. DOI: 10.1007/BF03055298.

[54] Tambs, K. \& Moum, T. (1993). How well can a few questionnaire items indicate anxiety and depression? Acta Psychiatrica Scandinavica,87, 364-367. DOI: 10.1111/j.16000447.1993.tb03388.x.

[55] Thelin, A. G. (1998). Working environment conditions in rural areas according to psychosocial indices. Annals of Agricultural and Environmental Medicine,5(2), 139-145.

[56] Torske, M. O., Hilt, B., Glasscock, D., Lundqvist, P. \& Krokstad, S. (2016). Anxiety and Depression Symptoms Among Farmers: The HUNT Study, Norway. Journal of Agromedicine, 21(1), 24-33. DOI: 10.1080/1059924X.2015.1106375.

[57] van de Schoot, R., Lugtig, P. \& Hox, J. (2012). A checklist for testing measurement invariance. European Journal of Developmental Psychology, 9(4), 486-492. DOI: 10.1080/17405629.2012.68674. 
[58] Vayro, C., Brownlow, C., Ireland, M. \& March, S. (2020). "Farming is not just an occupation [but] a whole lifestyle": A qualitative examination of lifestyle and cultural factors affecting mental health help-seeking in Australian farmers. Sociologia Ruralis, 60, 151-173. DOI: $10.1111 /$ soru.12274.

[59] Vesala, H. T. \& Vesala, K. M. (2010). Entrepreneurs and producers: Identities of Finnish farmers in 2001 and 2006. Journal of Rural Studies, 26(1), 21-30. DOI: 10.1016/j.jrurstud.2009.06.001.

[60] Vesala, K. M. \& Peura, J. (2005). Presentation of personal control in the rhetoric of farm families engaged in business diversification in Finland. Journal of Comparative Family Studies, 36, 443-473. DOI: 10.2307/41604025. 